\title{
Surveying Greek language instructors' beliefs about metaphor teaching
}

Ioannis Galantomos

Department of Mediterranean Studies, University of the Aegean, Greece

https://doi.org/10.36505/ExLing-2017/08/0009/000311

\begin{abstract}
The goal of this paper is twofold. Firstly to explore Greek language instructors' beliefs about the place of figurative language in foreign language pedagogy and secondly to examine their beliefs about metaphor teaching. It is widely accepted that language instructors bring to the classroom various views about all aspects of their work. In L2 instruction, vocabulary is an important component of a learner's communicative competence. Within vocabulary, metaphor awareness contributes to native-like fluency. Given the pervasiveness of metaphor in ordinary communication, we designed a small-scale study in order to survey Greek instructors' beliefs about its place in Greek as an L2 instruction. Our results are mixed. Pedagogical implications are discussed.
\end{abstract}

Key words: Greek as an L2, instructors' beliefs, vocabulary, metaphor teaching

\section{Introduction}

Over the past two decades, research has focused on the study of L2 teachers' beliefs (Niu \& Andrews 2012). Language instructors bring to the classroom certain views about all aspects of their work. These beliefs have to do with knowledge, their students, their discipline and instructional methods (Levin 2015). Teachers' beliefs are not static, but dynamic, contextrelated and shifting (Johnson 2009).

The major tenor of teacher beliefs' studies is related to the teaching of grammar, reading and writing (Borg 2006) with relatively few studies investigating L2 vocabulary and teachers' beliefs (Rossiter, Abbott \& Kushnir 2016). L2 vocabulary is deemed to be an important component of a learner's communicative competence (Read 2004). Within vocabulary, metaphor comprehension and production contribute to native-like fluency (MacLennan 1994).

Given the above, we conducted a small-scale experiment in order to investigate on the one hand Greek language instructors' beliefs about the place of figurative language in L2 instruction and on the other hand their beliefs regarding the teaching of metaphor.

ExLing 2017: Proceedings of 8th Tutorial and Research Workshop on Experimental Linguistics, 19-22 June, Heraklion, Crete, Greece 


\section{Method}

\section{Research questions}

Two research questions guided our study:

What are Greek language instructors' beliefs about figurative language (focus on metaphor)?

To what extent are Greek language instructors' beliefs about figurative language consistent with their teaching practices?

\section{Participants}

The sample of our study consisted of a total of 13 Greek language instructors who came from private and public Greek language centers in the greater area of Athens and taught at various CEFR (Common European Framework of Reference for Languages) levels. More specifically, 4 of them taught at A2, 3 at B1, 4 at B2 and the remaining 2 at C2 level. Regarding our participants' sex, 5 were males and 8 females. Their mid age was 28.2 years old. In addition, 10 of them were holders of an MA either in Linguistics (Applied or Theoretical) or Education.

\section{Instrument}

The metacognitive approach (with a focus on the metacognitive aspect of language learning) was followed to elicit our participants' beliefs. Within this approach, data are gathered through self reports (Barselos 2003).

\section{Procedure}

Our participants were asked to express their thoughts in written form with regard to the above mentioned (research) questions. For this assignment they were given 45 minutes. Upon completion, the essays were gathered and their wording was analyzed in order to identify the basic patterns regarding the two research questions.

\section{Results}

Our results are mixed. On the one hand, our participants believe that figurative language is closely related to L2 competence (research question 1). On the other hand, almost none of them taught metaphorical meanings and strategies of how Greek learners should deal with unknown figurative vocabulary (Research question 2). In particular, all of our participants $(100 \%)$ wrote that figurative is an essential component of L2 communicative competence. However, only 4 of them had incorporated figurative language into their syllabus (30\%). It is worth mentioning that those 4 instructors 
taught at B2 (2 instructors) (15\%) and C2 (2 instructors) (15\%) levels respectively.

\section{Discussion}

Our mixed findings can be attributed to certain beliefs and teaching practices in use in Greece with regard to figurative language. Traditionally, figurative language lies at the periphery of L2 teaching (Thornbury 2002). Nevertheless, recent studies have demonstrated that figurative language is ubiquitous in everyday communication and that it performs key functions in discourse (Semino 2008). Therefore, the ability to use figurative language appropriately can enhance a learners' overall communicative competence (Littlemore \& Low 2006). Under this perspective, Littlemore, Krennmayr, Turner \& Turner (2014) suggest that learners' familiarization with figurative language should start at CEFR A2 level onwards.

In Greece, the curriculum designed by the Centre for the Greek Language (Gr. $K E \Gamma$ ) (i.e. the official state organization for the world-wide certification

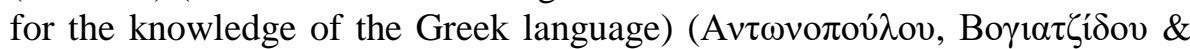

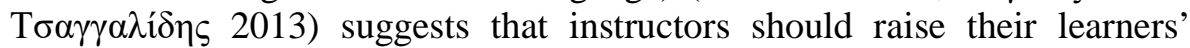
awareness of figurative language at $\mathrm{C} 2$ level. In addition and based on empirical data, few textbooks (especially at lower CEFR levels) introduce figurative language to Greek learners. Hence, our findings are not surprising. Our participants' beliefs are in line with those reported in literature (e.g. Kalyuga \& Kalyuga 2008) regarding the beneficial contribution of figurative language in L2 vocabulary teaching. On the other hand, present curriculum of Greek as an L2 does not offer learners the opportunity to realize the systematic nature of figurative language.

In light of the above, it is essential for curriculum designers to introduce figurative language from early on, taking into consideration the various functions it serves at different CEFR levels (cf. Littlemore et al. 2014). Additionally, Greek language instructors should raise their learners' awareness of the pervasiveness of figurative language through various activities based on authentic material. This technique has been proven to be beneficial for expanding learners' vocabulary size (e.g. Boers 2004). Finally, specialized seminars should take place so as to familiarize Greek language instructors with the place and functions of figurative language and to revitalize instructional methods.

\section{Conclusions}

To sum up, the results of our survey reveal a mixed situation regarding our research questions. On the one hand, it is accepted that figurative language plays an important role in L2 instruction and on the other hand its teaching 
has not yet received its proper place in Greek as an L2 instruction. In light of these findings certain teaching implications are discussed.

\section{References}

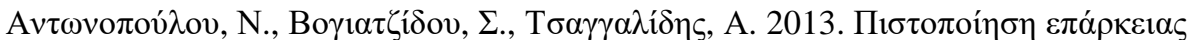

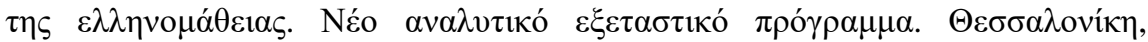
ҮПАІӨПА \& КЕГ.

Barcelos, A.M.F. 2003. Teachers' and students' beliefs within a Deweyan framework: Conflict and influence. In Kalaja, P., Barcelos, A.M.F. (eds.) 2003, Beliefs about SLA, 7-33. Dordrecht, Kluwer..

Boers, F. (2004). Expanding Learners' Vocabulary Through Metaphoric Awareness: What Expansion, What Learners, What Vocabulary? In Achard, M., \& Niemeier, S. (eds) 2004, Cognitive Linguistics, Second Language Acquisition, and Foreign Language Teaching, 211-232. Berlin \& New York, Mouton de Gruyter.

Borg, S. 2006. Teacher cognition and language education: Research and practice. London, Continuum.

Johnson, K.E. 2009. Second Language Teacher Education: A Sociocultural Perspective. New York \& London, Routledge.

Kalyuga, M. \& Kalyuga, S. 2008. Metaphor awareness in teaching vocabulary. Language Learning Journal 36/2, 249-257.

Levin, B.B. 2015. The Development of Teachers' Beliefs. In Fives, H. \& Gill, M.G. (eds.) 2015, International Handbook of Research on Teachers' Beliefs, 48-65. New York \& London, Routledge.

Littlemore, J. \& Low, G. 2006. Figurative thinking and foreign language learning. Basingstoke, Palgrave Macmillan.

Littlemoe, J., Krennmayr, T., Turner, J. \& Turner, S. 2014. An Investigation into Metaphor Use at Different Levels of Second Language Writing. Applied Linguistics 35/2, 117-144.

MacLennan, C.H. 1994. Metaphors and prototypes in the learning teaching of grammar and vocabulary. IRAL 32/2, 97-110.

Niu, R. \& Andrews, S. 2012. Commonalities and discrepancies in L2 teachers' beliefs and practices about vocabulary pedagogy: A small culture perspective. TESOL Journal, 6, 134-154.

Read, J. 2004. Research in Teaching Vocabulary. Annual Review of Applied Linguistics 24, 146-161.

Rossiter, M.J., Abbott, M.L. \& Kushnir, A. 2016. L2 Vocabulary Research and Instructional Practices: Where Are the Gaps? TESL-EJ 20/1, 1-25.

Semino, E. 2008. Metaphor in Discource. Cambridge, CUP.

Thornbury, S. 2002. How to teach vocabulary. Harlow, Pearson Longman. 